\title{
Coal Mining Energy Utilization and Environmental Impact Management Strategy Using the LCA Method
}

\author{
Frances Roi Seston Tampubolon*†, Arief Sabdo Yuwono**, Armansyah Halomoan Tambunan*** and Noer \\ Azam Achsani**** \\ *Natural Resources and Environmental Management, IPB University, 16177, Indonesia \\ **Department of Civil and Environmental Engineering, IPB University, Bogor, 16680, Indonesia \\ ***Department of Mechanical and Biosystems Engineering, IPB University, Bogor, 16680, Indonesia \\ $* * * *$ School of Business, IPB University, Bogor, 16151, Indonesia \\ $†$ Corresponding author: Frances Roi Seston Tampubolon; roipb19frances@apps.ipb.ac.id
}

\section{Nat. Env. \& Poll. Tech. Website: www.neptjournal.com \\ Received: 08-05-2021 \\ Revised: $02-07-2021$ \\ Accepted: 15-07-2021 \\ Key Words: \\ Coal mining \\ Global warming \\ Heavy equipment \\ Life cycle assessment}

\begin{abstract}
Coal mining processing and the clearing of land require that materials which have been removed be carefully inspected before it is reused. In this study, the boundary of our model starts with excavation and ends with material recovery. Therefore, further processing of the material to be recovered (recycling, reprocessing) is excluded from the model. In this study, the topsoil layer was collected in three pits numbered one, two, and three, from January to December 2020. The use of the LCA method gives results after the inventory data is carried out, which results in global warming. The results showed material removal unit process generated a total $\mathrm{CO}_{2}$ value of $32.44 \mathrm{~kg} \mathrm{CO}_{2}$ - eq.tonne-1 of coal, and the coal mining unit process generated a total $\mathrm{CO}_{2}$ value of $255.99 \mathrm{~kg} \mathrm{CO}_{2}$ - eq.tonne-1 of coal, for the impact of global warming. When compared to the material removal process, the results of the coal mining unit process show the highest global warming impact. Coal processing gives a yield of $25.61 \mathrm{~kg}$ $\mathrm{CO}_{2}$ - eq.tonne ${ }^{-1}$ of coal. So that the resulting impact as a whole is $314 \mathrm{~kg} \mathrm{CO}_{2}$ - eq.tonne ${ }^{-1}$ of coal. The total emissions resulting from B30 fuel (314 kg CO $2^{-}$eq.tonne ${ }^{-1}$ of coal) are smaller than $\mathrm{B} 20$ fuel (320 $\mathrm{kg} \mathrm{CO}_{2}$ - eq.tonne ${ }^{-1}$ of coal), $6 \mathrm{~kg} \mathrm{CO}_{2}$-eq.tonne ${ }^{-1}$ of coal. The coal mining process includes fuel used in coal extraction, coal hauling, coal stockpiling, blasting, water pumps, and water tracks.
\end{abstract}

\section{INTRODUCTION}

Before extracting coal mining materials, the first thing that must be done is land clearing (Arinaldo \& Adiatama 2019). Land clearing requires the use of heavy equipment based on the conditions and shape of the land. In the land clearing process, materials which have been removed must be carefully inspected before it is reused (Hogland et al. 2018). We specifically assessed the impacts of climate change on desertification, land degradation, and food security, and these impacts are evaluated separately (Hogland et al. 2018). In this study, the boundary of our model starts with excavation and ends with material recovery.

Therefore, further processing of the material to be recovered (recycling, reprocessing) is excluded from the model (Gusca et al. 2015). Dozers are one type of heavy equipment used for land clearance. After the land has been prepared for the next process, the heavy equipment for the excavation stage is designed according to the specifications and purpose. For the removal of topsoil layers, the heavy equipment that will be combined for excavating process are excavators, dozers, graders, dump trucks, and compactors (vibrators) (Katta et al. 2020). Before the heavy equipment is used, the production department's manager prepares the necessary combinations to match the specifications, keeping in mind the difficulties of removing the topsoil layer (Agwa-Ejon \&Pradhan 2018). The heavy equipment that can be used are excavator (PC 700) and dump truck (DT 740 and DT 741) This equipment's specifications are also essential so that the removal of the topsoil layer is carried out more efficiently and on time. Furthermore, it can minimize the amount of fuel needed in the process (Farjana et al. 2020). It has been shown that different forms of energy derived from fossil fuels can be combined, known as e-fuel (Mahmud et al. 2018, Ioakimidis et al. 2019, Andersson \& Börjesson 2021). It is important to combine heavy equipment used at the mine site. (Shaddad 2017, Lodhia 2018). In addition to reducing fuel use, it will also save time when removing the topsoil layer. In this study, the topsoil layer was collected from three pits numbered one, two, and three, from January to December 2020. 
For each pit, there are several fleets on each front that it makes. The front is defined as a location where heavy equipment transports topsoil to a temporary stockpile. Usually, on one front, there are about 2 or 3 fleets. A combination of heavy equipment is used at every fleet. Apart from heavy equipment, other supporting heavy equipment such as graders and vibrators will also be used. The graders and vibrators will improve the condition of the mine road so that it may be traversed more easily.

The primary activity in the coal mining industry is coal extraction. Coal extraction is a continuation of the waste reduction process. The areas to be mined are decided once the topsoil and subsoil layers have been properly removed. Thus, the coal is extracted for sending to the stock pile. It is important to have coal cleaning activity in order to mine the coal (coal obtaining). The purpose of coal cleaning is to remove impurities off the surface of coal (coal face) in the form of minor waste material soil, as well as other impurities caused by precipitation agents (surface water, rainwater, avalanches). Following that, the coal extraction process continues until the coal is loaded onto the vehicle.

The use of heavy equipment requires energy for removing/extracting topsoil layers. The average energy needed for seven mines is summarized where the energy requirement is broken down into six components: crushing, grinding, processing, tailings, process water, general plant (Jeswiet \& Szekeres 2016). Energy requirements for both open pit and underground mines include electricity and a variety of carbon fuels: natural gas, propane gas and diesel fuel. Both open pit and underground operations are very different and have different energy needs, for instance, underground mines have HVAC energy needs, whereas open pit mines do not. (Jeswiet \& Szekeres 2016). The energy source for this study is the same as that used by dump trucks, excavators, graders, and vibrators. Biodiesel B30 is the fuel used. B30 energy is used in coal production by only a few mining businesses. The use of B30 energy has a number of advantages and disadvantages. In this study, the advantages and disadvantages will be examined further using the LCA technique. Compared to $100 \%$ diesel, it will be seen which part gives an excess efficiency in the excavation process.

Life cycle assessment or LCA is a methodology for assessing environmental impacts associated with all the stages of the life cycle of a commercial product, process, or service (ISO14044 2006). Biodiesel and electricity energy sources will be input data in the LCA. The final stage is to interpret the impact category study that has been carried out. The LCA stages follow (SNI ISO14004 2016) standards that contain general information, namely: goal and scope of LCA, LCI phase, LCIA phase, interpretation phase, report and critical review, limitations, relationship phase, conditions for the use of value choices, and optional elements (Fig. 1).

Stages, such as interpretation, will be carried out using the LCA technique. This part of the process uses a systematic approach to identify, test, study, evaluate, and deliver conclusions based on the findings of the LCA. It's done to meet the application requirements outlined in the study's objectives and scope.

\section{MATERIALS AND METHODS}

The research was conducted at PT. Bukit Asam Tbk (Persero), located in the village of Tanjung Enim Market, Lawang Kidul District, Muara Enim Regency, South Sumatra. The investigation began in August 2020. LCA is used to achieve the objective of this study. The LCA method is carried out based on the LCA principles and framework in (ISO14040 2006). The objective is to estimate the environmental impact of coal mining management using biodiesel (B30) as a substitute for fuel and an energy source to produce 1 ton of Coal (functional unit) as the final product.

\section{Goal and Scope}

This study uses the LCA method to estimate coal mining management's environmental impact using electricity, biodiesel (B30), and blasting material as an energy source to produce 1 ton of coal (function unit) as the final product.

\section{Inventory Data Collection}

There are three types of data in the life cycle inventory (LCI): primary data, generic data, and estimation data, as presented in Fig. 1.

\section{Primary Data}

Primary data was obtained directly from the company and then entered as inventory data. Data obtained directly from the company can be used immediately and does not undergo data processing, but some must be processed to get the same unit (unit) as the entry system used in the LCA. The data obtained from the company is in the form of input and output of the coal production per month during 2020 from the material removal process unit. The data obtained from the material removal process is fuel (B30) used by heavy equipment. For example, open-pit transportation (rock removal) uses 30\% energy for waste and 24\% energy for ore disposal (Jeswiet et al. 2015, Jeswiet \& Szekeres 2016). Heavy equipment used in the material removal process includes dozers, excavators, graders, compactors, and several other supporting heavy equipment (Fig. 2 \& Fig. 3). 
In addition to input and output data for the coal production process, input, output, and emission data is also obtained from the coal mining process unit, including coal extracting, coal hauling and coal stockpiling (Fig. 3 and Fig. 4). The data obtained from the material removal process will provide results of the process using alternative fuels (biodiesel B30) and the resulting emissions. First, the LCA assesses the environmental costs (Zhou et al. 2021, Ezeokoli et al. 2021). Second, it is linked to a product, process, or activity by identifying and quantifying the amount of energy and materials used, as well as the waste that is released into the environment.

\section{Generic Data}

Generic data is an average value that represents a value based on the preliminary information that has been obtained. In this process, the initial data acquired will be processed to have a relationship with data originating from the material removal process unit to produce a production process flow.

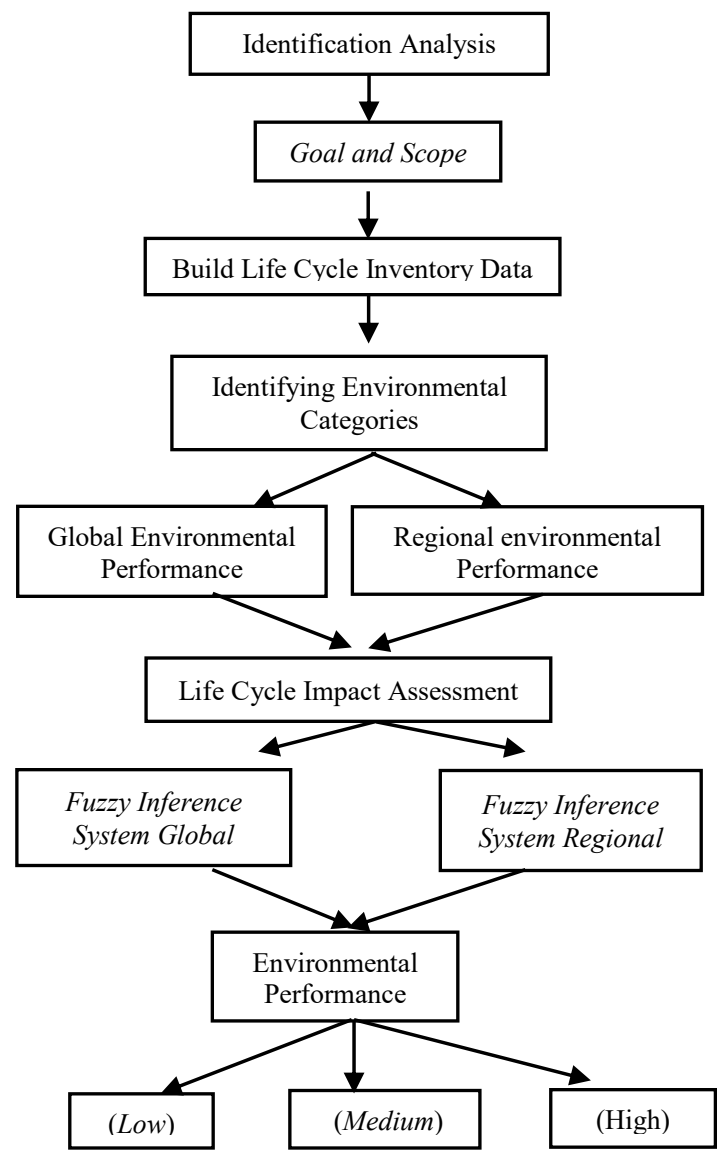

Fig. 1: Stages of the LCA method and fuzzy inference system.

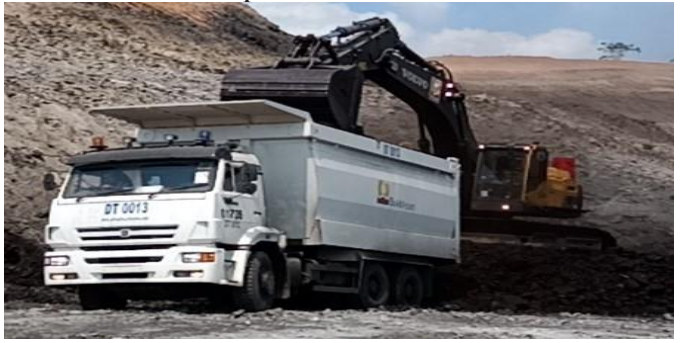

Fig. 2: Dump truck and excavator in Pit 1.

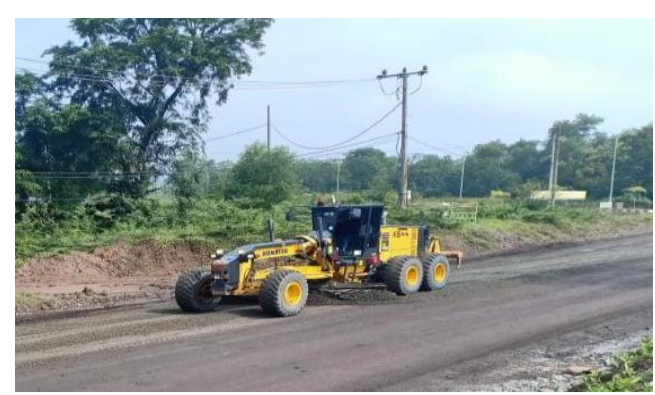

Fig. 3: Grader (coal hauling). 
The data of the production flow will be modified into one process flow based on the process unit data.

\section{Estimated Data}

The data that has been collected from the industry can be done by estimation. It is because not all data can be obtained from industry. To obtain a complete data flow, we estimate by completing the current values. At this stage, an estimate is made to determine energy use during the mining process. The estimation process is carried out by using reports and obtaining data online from employees.

\section{Data Analysis}

It consists of four stages, namely the goals and scope (goal and scope definition), analysis of input and output inventories (life cycle inventory analysis), environmental impact assessment from inventory data (life cycle impact assessment), and life cycle interpretation. The Open LCA database is used to achieve goal 1 in this study, as presented in Table 1 (Intergovernmental Panel on Climate Change 2014)(USEPA AP 42 1995).

The initial stage of LCA analysis is determines the goal and scope (goal and scope definition) of the analysis (study). The purpose here is to estimate the environmental impact of coal mining management using biodiesel (B30) as a fuel and energy source to generate 1 tonne of coal (functional unit) (Fig. 5). The aim of the LCA study will be decided, as well as the limitations or scope of the LCA implementation. The LCA study will be carried out more systematically and directly if a clear purpose and scope is established. Finally, the use of LCA as a comparison in various cases was carried out as per ISO 140442006.
The coal products that will be used by users (consumers) are PLN and PLTU. The restrictions imposed will limit the raw materials that can be used in the final product.

The data that we have obtained and have become inventory data will be factored using a characterization factor. The factor derived from the characterization model is to convert the life cycle inventory results into general units of category indicators (SNI ISO14004 2016). The goal is to see the flow diagram of each unit process carried out at the mine site, and there is a process flow, as shown in Fig. 5 below. The unit process starts from stripping, blasting, overburden hauling, mining, coal processing, and the final coal product with a functional unit of 1 ton of coal.

The relationship between impact indicators, inventory data, and characterization factors is shown in the table presented in Table 1.

The next stage is to carry out normalization and to get an impact indicator. Normalization is the calculation of the size of a category indicator relative to some reference information. The purpose of normalization is to better understand each indicator's comparable magnitude from the product system under study. It is an optional element that can be useful. Some of the normalizations that can be done include: checking for inconsistencies, providing and communicating relatively important indicator result information, and preparing additional procedures, such as grouping, weighting, or life cycle interpretation. The definition of weighting is converting indicators from different impact categories using numerical factors based on choice values. Therefore, weighting methodologies should play an essential role in simplifying LCA output, which would

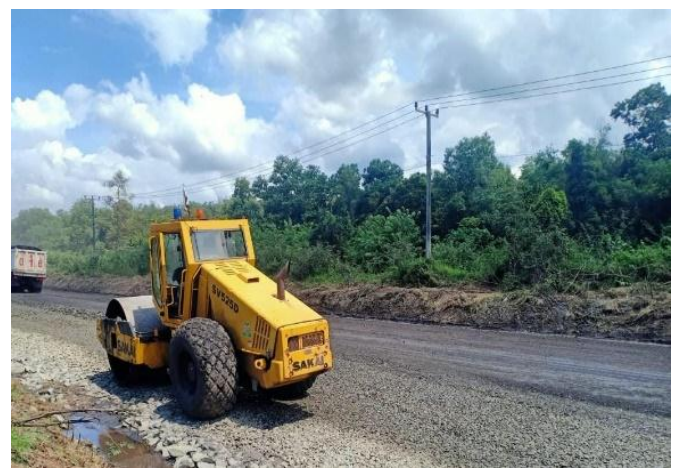

Fig. 4: Compactor (coal mining).

Table.1: The relationship between inventory data and characterization factors.

\begin{tabular}{|lll|}
\hline Amount & Emissions & Characteristic Factors \\
\hline The amount consumed by the process (input) & Emissions released per input unit & $\begin{array}{l}\text { Characterization factors of impact categories } \\
\text { (IPCC, GWP) }\end{array}$ \\
\hline
\end{tabular}


ultimately help identify priorities and define environmental strategies (Vargas-Gonzalez et al. 2019). It can include the aggregation of the results of the weighted indicators. Weighting is an element of choice with two possible procedures: converting the development of the indicator or normalization using the selected weighting factor or combining the corrected or normalized indicator results from all impact categories. Weighting measures are based on choice values and are not scientific. Weighting, one of the steps in LCIA, integrates the various environmental impacts by assigning relative importance to each impact category (Ji \& Hong 2016, Curran 2015).
It can be done by analyzing the impact of the data on the number of inputs entered into the inventory data to see the effect on the environment (McKone et al. 2011, Berrill et al. 2016). The material removal process unit will enter input data, such as fuel for topsoil (overburden) and electricity, as previously stated. In a mining operation, LCA can be used to identify the conditions that need to be improved in order to improve the environment (Pell et al. 2019). For the fuel used in this process unit and topsoil removal and transportation of the top layer, B30 biodiesel fuel is also used for watering roadways at the mine site.

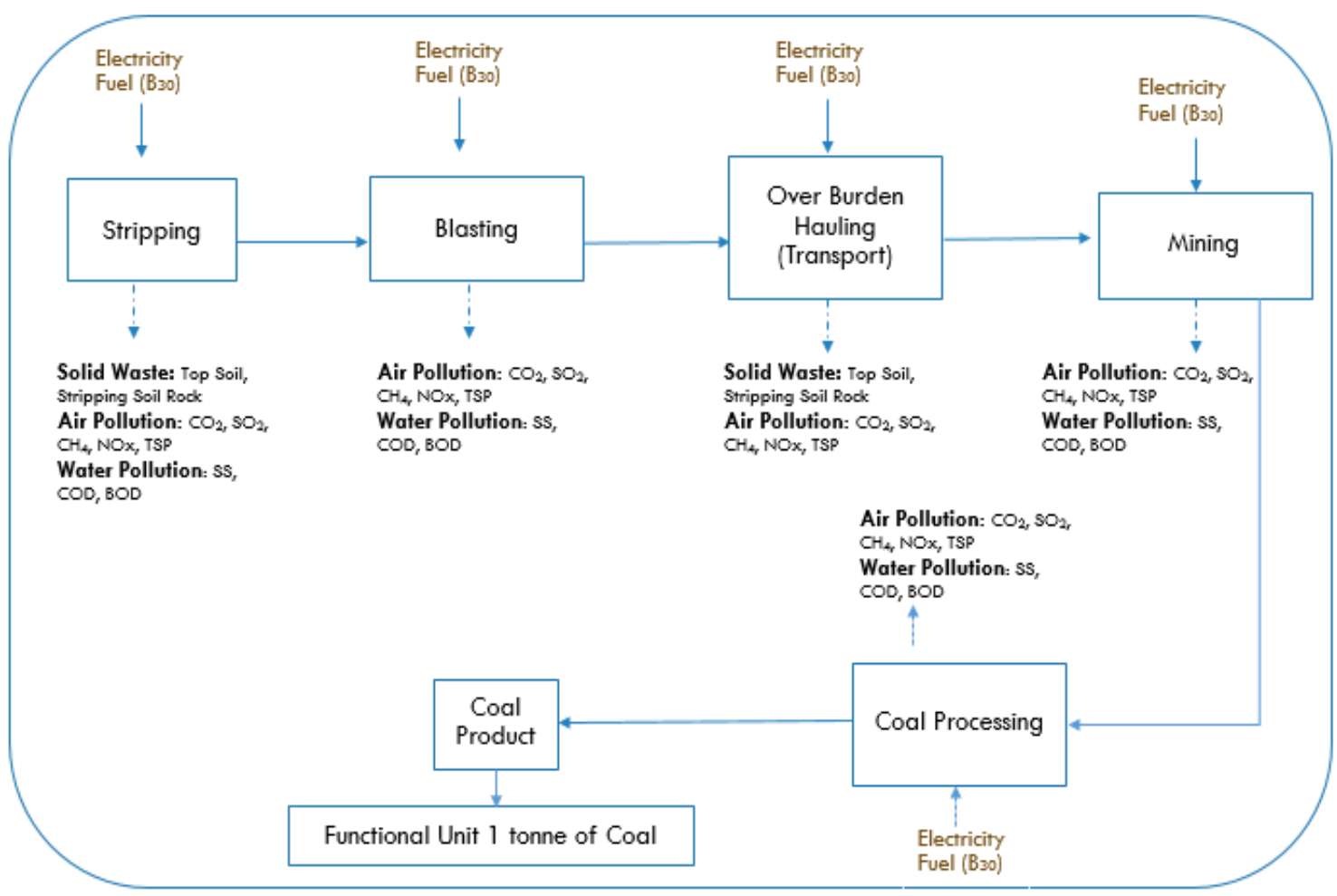

Fig. 5: Boundary system of the LCA process unit.

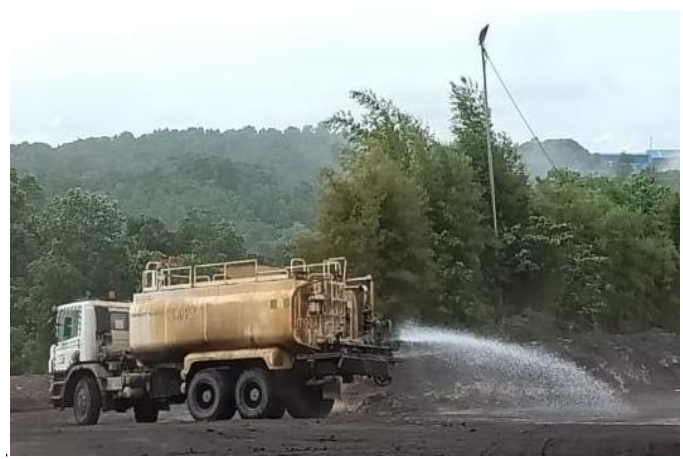

Fig. 6: Watering for mine road. 
After the material removal process unit, the next process unit is coal mining. The processing unit data was fed into the inventory data (coal extracting, coal hauling, and coal stockpiling, transportation for blasting material, explosive material for blasting, electricity, and mine watering and pump for water treatment) as shown in Fig. 6. This process unit produces a coal product as its output.

We use distinguishing factors to determine the impact category from the inventory data entered in the LCA stage. Distinguishing characteristics can use data from databases from both open LCA, Gabi and Simapro.

\section{RESULTS AND DISCUSSION}

The percentage and contribution of the heavy equipment used are shown in Table 2 below. These figures show the $\mathrm{kg} \mathrm{CO}_{2}$-equivalent emissions produced by each process unit. These figures show the kg. $\mathrm{CO}_{2}$-eq.tonne-1 emissions produced by each process unit. Each processing unit has uses a type of heavy equipment. Meanwhile, the energy source required is electricity taken from the State Electricity Company (PLN), B30 biodiesel fuel, and blasting material used for blasting. Each of these energy sources has different categorical factors. The (Intergovernmental Panel on Climate Change 2014)(EPA and Standards 2003) database was used as definite factors (David \& Khanda 2001). The loading and transportation of iron ore (67 percent of total mining emissions) produces the largest GHG emissions, as diesel-powered loaders and trucks are needed to extract ore from the mine for further extraction. According to Tarnoczi (2013), the LCA transportation model was constructed for transportation of oil sands products by pipeline and rail.

The second-largest contributor is vegetation and soil removal, which includes GHG emissions from microbial decomposition of removed biomass and soil, as well as a decrease in photosynthetic productivity over the mine's life. The contribution to the loading and transportation of coal was $255.99 \mathrm{~kg} . \mathrm{CO}_{2}$-eq.tonne $\mathrm{e}^{-1}$ or $81.5 \%$ of the total emissions of $314 \mathrm{~kg} . \mathrm{CO}_{2}$-eq.tonne ${ }^{-1}$. In this study, the identical results for the second contribution are material removal or those related to soil removal, as shown in Tables 2 and 3.

The amount of emissions produced by the coal-hauling process unit is also shown in Table 2. It means that the process of transporting waste and coal materials requires quite a large amount of biodiesel fuel. Another thing that is very important and needs to be considered is the condition of the mine road (Wolfgang \& Burgess-Limerick 2014). Before each assessment and consequently, each measurement, the road is classified according to one of three categories: maintained, which occurs in graded surfaces, rough which is usually found in new exploitation areas or after wet weather

Table 2: Impact category each proses unit (B30) (The year 2020).

\begin{tabular}{|c|c|c|c|c|c|}
\hline \multirow[t]{2}{*}{ No } & \multirow[t]{2}{*}{ Process Unit } & \multicolumn{3}{|c|}{ Impact Category } & \multirow{2}{*}{$\begin{array}{l}\text { Total } \mathrm{kg} \mathrm{CO}_{2} \text {-eq. } \\
\text { tonne }{ }^{-1} \text { of coal }\end{array}$} \\
\hline & & $\mathrm{kg} \mathrm{CO}_{2}$ & $\mathrm{~kg} \mathrm{CH}_{4}$ & $\mathrm{~kg} \mathrm{~N}_{2} \mathrm{O}$ & \\
\hline 1 & Fuel for Top Soil and Waste & 27.74 & 0.04 & 0.44 & 28.22 \\
\hline 2 & Electricity for Mine Site Lighting Lamps (Material Removal) & 3.33 & & & 3.33 \\
\hline 3 & Water Truck for Watering the Mine Road & 0.87 & 0.00 & 0.01 & 0.89 \\
\hline 4 & Total $\mathrm{kg} \mathrm{CO}_{2}$-eq.tonne ${ }^{-1}$ of Coal (Material Removal) & & & & 32.44 \\
\hline 5 & Coal Extraction, Coal Hauling, Coal Stockpiling & 3.10 & 0.01 & 0.07 & 3.18 \\
\hline 6 & Transportation for Blasting Material & 0.21 & 0.00 & 0.00 & 0.21 \\
\hline 7 & Explosive Material for Coal Blasting & 0.54 & & & 0.54 \\
\hline 8 & Electricity for Mine Site Lighting Lamps (Coal Mining) & 5.61 & & & 5.61 \\
\hline 9 & Water Truck for Watering the Mine Road & 0.96 & 0.00 & 0.02 & 0.98 \\
\hline 10 & Water Pump for Water Treatment & 1.56 & 0.00 & 0.02 & 1.59 \\
\hline 11 & Coal Operation & & 243.88 & & 243.88 \\
\hline 12 & Total $\mathrm{kg} \mathrm{CO}_{2}$-eq. tonne ${ }^{-1}$ of Coal (Coal Mining) & & & & 255.99 \\
\hline 13 & Fuel (Coal Crusher, Coal Stacking as Product) & 2.33 & 0.00 & 0.04 & 2.37 \\
\hline 14 & Electricity for Mine Site Lighting Lamps (Coal Processing) & 3.12 & & & 3.12 \\
\hline \multirow[t]{3}{*}{15} & Coal As Received (Pasca Mining) & & 20.12 & & 20.12 \\
\hline & Total kg CO${ }_{2}$-eq.tonne ${ }^{-1}$ of Coal (Coal Processing) & & & & 25.61 \\
\hline & Total of all & & & & 314 \\
\hline
\end{tabular}


conditions or combination, which means the variety of both maintained and uneven (Duarte et al. 2020).

In general, the results from the unit process made the most significant contribution, especially during the coal transportation operation, which generated $255.99 \mathrm{~kg}$. $\mathrm{CO}_{2}$-eq. tonne ${ }^{-1}$ of coal.

The results given from the impact analysis give a value of 32.44 tonnes of $\mathrm{CO}_{2}$-eq.tonne ${ }^{-1}$ coal for material removal process. The activity describes the biodiesel fuel used in the process unit for each tonne of coal produced. Energy is needed to extract topsoil and waste, to light the mine site during excavation using electricity, to remove and dispose waste material, and watering the mine road that the dump truck traverses.

Furthermore, the findings from the coal mining process unit, shows a yield value of $255.99 \mathrm{~kg} . \mathrm{CO}_{2}$.eq.tonne ${ }^{-1}$ coal.

Table 3: Impact category each process unit (B20 \&B30) (The Year.2020).

\begin{tabular}{|c|c|c|c|c|c|c|c|c|c|}
\hline \multirow[t]{3}{*}{ No } & \multirow[t]{3}{*}{ Process Unit } & \multicolumn{4}{|c|}{$\mathrm{B}_{20}$} & \multicolumn{4}{|c|}{$\mathrm{B}_{30}$} \\
\hline & & \multicolumn{3}{|c|}{ Impact Category } & \multirow{2}{*}{$\begin{array}{l}\text { Total } \mathrm{kg} \mathrm{CO}_{2} \text {-eq. } \\
\text { tonne }{ }^{-1} \text { of coal }\end{array}$} & \multicolumn{3}{|c|}{ Impact Category } & \multirow{2}{*}{$\begin{array}{l}\text { Total } \mathrm{kg} \mathrm{CO}_{2} \text {-eq. } \\
\text { tonne }{ }^{-1} \text { of coal }\end{array}$} \\
\hline & & $\mathrm{kg} \mathrm{CO}_{2}$ & $\mathrm{~kg} \mathrm{CH}_{4}$ & $\mathrm{~kg} \mathrm{~N}_{2} \mathrm{O}$ & & $\mathrm{kg} \mathrm{CO}_{2}$ & $\mathrm{~kg} \mathrm{CH}_{4}$ & $\mathrm{~kg} \mathrm{~N}_{2} \mathrm{O}$ & \\
\hline 1 & $\begin{array}{l}\text { Fuel for Top Soil dan } \\
\text { Over Burden }\end{array}$ & 32.42 & 0.04 & 0.44 & 32.90 & 27.74 & 0.04 & 0.44 & 28.22 \\
\hline 2 & $\begin{array}{l}\text { Electricity for Mine Site } \\
\text { Lighting Lamps (Material } \\
\text { Removal) }\end{array}$ & 3.33 & & & 3.33 & 3.33 & & & 3.33 \\
\hline 3 & $\begin{array}{l}\text { Water Truck for Watering } \\
\text { for the Mine Road }\end{array}$ & 1.02 & 0.00 & 0.01 & 1.04 & 0.87 & 0.00 & 0.01 & 0.89 \\
\hline 4 & $\begin{array}{l}\text { Total kg CO}{ }_{2} \text {-eq/tonne of } \\
\text { Coal (Material Removal) }\end{array}$ & & & & 37.26 & & & & 32.44 \\
\hline 5 & $\begin{array}{l}\text { Coal extracting, Coal } \\
\text { Hauling, Coal Stockpiling }\end{array}$ & 3.62 & 0.01 & 0.07 & 3.70 & 3.10 & 0.01 & 0.07 & 3.18 \\
\hline 6 & $\begin{array}{l}\text { Transportation for Blast- } \\
\text { ing Material }\end{array}$ & 0.24 & 0.0003 & 0.003 & 0.24 & 0.21 & 0.00 & 0.00 & 0.21 \\
\hline 7 & $\begin{array}{l}\text { Explosive Material for } \\
\text { Coal Blasting }\end{array}$ & 0.54 & & & 0.54 & 0.54 & & & 0.54 \\
\hline 8 & $\begin{array}{l}\text { Electricity for Mine Site } \\
\text { Lighting Lamps (Coal } \\
\text { Mining) }\end{array}$ & 5.61 & & & 5.61 & 5.61 & & & 5.61 \\
\hline 9 & $\begin{array}{l}\text { Water Truck for Watering } \\
\text { for the Mine Road }\end{array}$ & 1.12 & 0.00 & 0.02 & 1.14 & 0.96 & 0.00 & 0.02 & 0.98 \\
\hline 10 & $\begin{array}{l}\text { Water Pump for Water } \\
\text { Treatment }\end{array}$ & 1.82 & 0.0021 & 0.03 & 1.85 & 1.56 & 0.00 & 0.02 & 1.59 \\
\hline 11 & Coal Operation & & 243.88 & & 243.88 & & 243.88 & & 243.88 \\
\hline 12 & $\begin{array}{l}\text { Total } \mathrm{kg} \mathrm{CO}_{2} \text {-eq/ tonne of } \\
\text { Coal (Coal Mining) }\end{array}$ & & & & 256.96 & & & & 255.99 \\
\hline 13 & $\begin{array}{l}\text { Fuel (Coal Crusher, Coal } \\
\text { Stacking as Product) }\end{array}$ & 2.58 & 0.00 & 0.04 & 2.62 & 2.33 & 0.00 & 0.04 & 2.37 \\
\hline 14 & $\begin{array}{l}\text { Electricity for Mine Site } \\
\text { Lighting Lamps (Coal } \\
\text { Processing) }\end{array}$ & 3.12 & & & 3.12 & 3.12 & & & 3.12 \\
\hline 15 & $\begin{array}{l}\text { Coal As Received (Pasca } \\
\text { Mining) }\end{array}$ & & 20.10 & & 20.10 & & 20.12 & & 20.12 \\
\hline \multirow[t]{2}{*}{16} & $\begin{array}{l}\text { Total } \mathrm{kg} \mathrm{CO}_{2} \text {-eq/ tonne of } \\
\text { Coal (Coal Processing) }\end{array}$ & & & & 25.84 & & & & 25.61 \\
\hline & Total of all & & & & 320 & & & & 314 \\
\hline
\end{tabular}


This result demonstrates the greatest impact. Coal haulage, coal stockpiling, and coal operations in the coal extraction process require the most fuel. Table 3 shows the final result of the coal extracting process, which shows a yield of 25.61 $\mathrm{kg} . \mathrm{CO}_{2}$.eq.tonne ${ }^{-1}$ of coal. The majority of heavy equipment used in the coal mining process is for tasks such as coal hauling, coal extraction, water rails, and water pumps.

This tool uses biodiesel fuel and uses electricity obtained from the state electricity company (PLN). Transportation used is a dump truck to deliver materials. The blasting process also requires material for detonating and transportation to provide the material to the blasting site.

Energy consumption data for the loading and hauling fleet was collected as part of this study. Much of the equipment used in mining for material movement or haulage is powered by diesel engines. Diesel technologies demand a lot of energy, accounting for 87 percent of the energy used in materials handling (Norgate \& Haque 2010).

The results obtained in this study show a value of 7.6 $\mathrm{kg} . \mathrm{CO}_{2}$.eq.tonne ${ }^{-1}$ of coal in materials handling compared to a previous study that showed a value of $6.0 \mathrm{~kg} \cdot \mathrm{CO}_{2}$.eq.tonne ${ }^{-1}$ of ore in materials handling (Norgate \& Haque 2010). We compare the results obtained in this study, namely $81.5 \%$ of the total emissions from the cradle to gate activity. The result is almost similar to Norgate \& Haque (2010).

The results of the impact categories presented in table 3 illustrate the impacts they can have on human health, the environment, and other resources (Munawer 2018). According to Munawer (2018), the effect that is acceptable to humans is due to continuous $\mathrm{CO}_{2}$ emissions and underlying climate change; global warming is correlated with an increase in flood incidence and overall storm activity (Farjana et al. 2018, Hurlbert et al. 2019).

\section{CONCLUSION}

The results of the LCA process contribute to each of the processes that have been completed. However, some data related to material removal, coal mining, and coal processing is evaluated and estimated according to the conditions in the field. Although some data cannot be processed, the inventory data input process and categorical factors yield an approximate value.

The impact of metal production processes, particularly those linked to energy content and greenhouse gas emissions, on the environment can be seen from the value of the contribution of the mining and mineral processing phases to the environment.

The results that have been obtained from each process unit are:
1. Total material removal is $32.44 \mathrm{~kg} \cdot \mathrm{CO}_{2}$ eq.tonne ${ }^{-1}$ of coal.

2. Total coal mining is $255.99 \mathrm{~kg} \cdot \mathrm{CO}_{2}$ eq.tonne ${ }^{-1}$ of coal.

3. Total coal processing is $25.61 \mathrm{~kg} \cdot \mathrm{CO}_{2}$.eq.tonne ${ }^{-1}$ of coal.

The results obtained in the coal mining process unit gave $81.5 \%$ of the total emission produced. Therefore, the total emissions resulting from $\mathrm{B} 30$ fuel $\left(314 \mathrm{~kg} \cdot \mathrm{CO}_{2}\right.$.eq.tonne ${ }^{-1}$ of coal) are smaller than $\mathrm{B} 20$ fuel $\left(320 \mathrm{~kg} \cdot \mathrm{CO}_{2}\right.$. eq.tonne ${ }^{-1}$ of coal), $6 \mathrm{~kg} . \mathrm{CO}_{2}$ eq.tonne ${ }^{-1}$ of coal. The coal mining process includes fuel used in coal extracting, coal hauling, coal stockpiling, blasting, water pumps, water tracks. Meanwhile, the state electrical corporation provides electricity for mining street lighting (PLN).

\section{ACKNOWLEDGEMENT}

This research was funded by the Education Fund Management Agency (LPDP) from the Ministry of Finance of the Republic of Indonesia.

\section{REFERENCES}

Agwa-Ejon, J.F. and Pradhan, A. 2018. Life cycle impact assessment of artisanal sandstone mining on the environment and health of mineworkers. Environ. Impact Assess. Rev., 72(10): 71-78..

Andersson, Ö. and Börjesson, P. 2021. The greenhouse gas emissions of an electrified vehicle combined with renewable fuels: Life cycle assessment and policy implications. Appl. Energy, 289: 6621.

Arinaldo, D. and Adiatama, J.C. 2019. The dynamics of Indonesian coal: Towards a fair energy transition. Inst. Essent. Serv. Reform, 4(5): 31-49

Berrill, P., Anders, A., Yvonne, S., Hans, C.G. and Edgar, G.H. 2016. Environmental impacts of high penetration renewable energy scenarios for Europe. Environ. Res. Lett., 11(1): 12-40

Curran, M.A. 2015. Life cycle assessment: A systems approach to environmental management and sustainability. Chem. Eng. Prog., 111(10): 26-35.

David, C.W. and Khanda, D. 2001. Application of life cycle assessment. Energy, 11(3): 1-20 https://doi.org/10.1201/9780203907931.ch16.

Duarte, J., Branco, J.C., Matos, M.L. and Santos, J.B. 2020. Understanding the whole-body vibration produced by mining equipment as a role-player in workers' well-being: A systematic review. Extr. Indust. Soc., 7(4): 1607-23.

EPA, U.S. and Office of Air Quality Planning and Standards. 2003. Wood Residue Combustion In Boilers. AP 42, Compilation of Air Pollutant Emission Factors, Volume 1 Stationary Point and Area Sources, pp. $1-20$.

Ezeokoli, O.T., Oluwatosin, G., Oladipo, C., Bezuidenhout, C., Adeleke, R.A. and Maboeta, M.S. 2021. Assessing the ecosystem support function of South African coal mining soil environments using earthworm (Eisenia Andrei) bioassays. Appl. Soil Ecol., 157(5): 103771.

Farjana, S.H., Nazmul H., and Parvez Mahmud,M.A. 2018. Life-Cycle environmental impact assessment of mineral industries. IOP Conf. Series: Mater. Sci. Eng., 351(1): 0-7.

Farjana, S.H., Parvez, M. and Nazmul, H.. 2020. Solar process heat integration in the lead mining process. Case Stud. Thermal Eng., 22(10): 100768.

Gusca, J., Maksims, F. and Indra, M. 2015. Life cycle assessment of landfill mining project. Energy Procedia, 72: 322-328. 
Hogland, M., Dace, ., Mait, K., Yahya, J., Fabio, K. and André Luís, D.S.K.O. 2018. Remarks on four novel landfill mining case studies in Estonia and Sweden. J. Mater. Cycles Waste Manag., 20(2): 1355-1363.

Hurlbert, M., Krishnaswamy, J., Davin, E., Johnson, F.X., Mena, C.F., Morton, J., Myeong, S., Viner, D., Warner, K. and Wreford, A.

2019. Risk Management and Decision-Making in Relation to Sustainable Development Coordinating. In Shukla, P.R., Skea, J.,

Calvo Buendia, E., Masson-Delmotte, V., Pörtner, H.O., Roberts, D.C., Zhai, P., Slade, R., Connors, S., Van Diemen, R., Ferrat,

M., Haughey, E., Luz, S., Neogi, S., Pathak, M., Petzold, J., Portugal Pereira, J., Vyas, P., Huntley, E., Kissick,

K., Belkacemi, M. and Malley, J. (eds.), Climate Change and Land: An IPCC Special Report on Climate Change, Desertification, Land Degradation,

Sustainable Land Management, Food Security, and Greenhouse Gas Fluxes in Terrestrial Ecosystems . In Press, pp.673-800.

Intergovernmental Panel on Climate Change. 2014. Climate Change 2014 Mitigation of Climate Change. Climate Change 2014 Mitigation of Climate Change. https://doi.org/10.1017/cbo9781107415416.

Ioakimidis, C.S., Alberto, M., Ali, B.D., Dimitrios, T. and Konstantinos, N.G. 2019. Life cycle assessment of a lithium iron phosphate (LFP) Electric vehicle battery in second life application scenarios. Sustainability, 11(9): 52 .

ISO14040. 2006. Standard, International Organization.

ISO14044. 2006. Standard, International Organization.

Jeswiet, J., Archibald, J., Thorley, U. and. De Souza, E. 2015. Energy use in premanufacture (mining). Procedia CIRP, 29: 816-21.

Jeswiet, J. and Alex Szekeres, A. 2016. Energy consumption in mining comminution. Procedia CIRP, 48:140-45.

Ji, C. and Hong, T. 2016. New Internet search volume-based weighting method for integrating various environmental impacts. Environ. Impact Assess. Rev., 56: 128-38.

Katta, A.K., Matthew, D. and Kumar, A. 2020. Development of disaggregated energy use and greenhouse gas emission footprints in Canada's iron, gold, and potash mining sectors. Resour. Conserv. Recycl., 152: 104485.

Lodhia, S.K. 2018. Mining and Sustainable Development: Current Issues. Routledge, England, UK.
Mahmud, M.A.P., Nazmul, H., Shahjadi, H.F. and Candace, L. 2018. Environmental impacts of solar-photovoltaic and solar-thermal systems with life-cycle assessment. Energies, 11(9): 46. https://doi. org/10.3390/en11092346.

McKone, T.E., Nazaroff, W.W., Berck, P., Auffhammer, M., Lipman, T., Torn, M.S. and Masanet, E. 2011. Grand challenges for life-cycle assessment of biofuels. Environ. Sci. Technol., 45(5): 1751-56.

Munawer, M.E. 2018. Human health and environmental impacts of coal combustion and post-combustion wastes. J. Sustain. Mining, 17(2): $87-96$.

Norgate, T. and Haque, N. 2010. Energy and greenhouse gas impacts of mining and mineral processing operations. J. Cleaner Prod., 18(3): 266-74.

Pell, R., Laurens, T., Palmer, L.W.H, Glass, X.Y., Frances,W., Xianlai, Z. and Jinhui, L. 2019. Environmental optimization of mine scheduling through life cycle assessment integration. Resour. Conserv. Recycl., 142(12): 267-76.

Shaddad, A. 2017. Analysis of the compatibility of mechanical equipment (match factor) for increased productivity. J. Geo., 4(3): 74.

SNI ISO14004. 2016. SNI ISO 14004 Sistem Manajemen Lingkungan - Pedoman Umum Dalam Penerapan Environmental Management Systems - General Guidelines on Implementation, pp. 1-122.

USEPA AP 42. 1995. AP 42, Fifth Edition Compilation of Air Pollutant Emission Factors, Volume 1: Stationary and Point Sources, pp. 1-10.

Tarnoczi, T. 2013. Life cycle energy and greenhouse gas emissions from transportation of Canadian oil sands to future markets. Energy Policy, 62: 107-17.

Vargas-Gonzalez, M., François, W., Patricia, M., Laurent, G., Sébastien, H., Olivier, J., Rosalie, V.Z and Jacques, L. 2019. Operational life cycle impact assessment weighting factors based on planetary boundaries: applied to cosmetic products. Ecol. Indicators, 107(4): 105498.

Wolfgang, R. and Burgess-Limerick, R. 2014. Whole-body vibration exposure of haul truck drivers at a surface coal mine. Appl. Egron., 45(6): 1700-1704.

Zhou, Y., Feng, L. and Tao, Z. 2021. An experience-based mining approach to supporting urban renewal mode decisions under a multi-stakeholder environment in China. Land Use Policy, 106: 105428. 